\title{
Synthesis of 1,2,3-Triazole Derivatives of 4,4'-Dihydroxybenzophenone and Evaluation of Their Elastase Inhibitory Activity
}

\author{
Maria C. F. Dias, ${ }^{a}$ Thiago Q. Gularte, ${ }^{a}$ Róbson R. Teixeira, ${ }^{\circledR *, a}$ Jorge A. N. Santos, ${ }^{b}$ \\ Eduardo J. Pilau, ${ }^{\oplus c}$ Tiago A. O. Mendes, ${ }^{d}$ Antônio J. Demuner ${ }^{a}$ and \\ Marcelo H. dos Santos ${ }^{a}$
}

${ }^{a}$ Departamento de Química, Universidade Federal de Viçosa, Avenida Peter Henry Rolfs, s/n, Campus Universitário, 36570-900 Viçosa-MG, Brazil

${ }^{b}$ Instituto Federal de Educação, Ciência e Tecnologia do Sul de Minas Gerais, Praça Tiradentes, 416, Campus Inconfidentes, 37576-000 Inconfidentes-MG, Brazil

'Departamento de Química, Universidade Estadual de Maringá, Avenida Colombo, 5790, Campus Universitário, 87020-900 Maringá-PR, Brazil

${ }^{d}$ Departamento de Bioquímica e Biologia Molecular, Universidade Federal de Viçosa, Avenida Peter Henry Rolfs, s/n, Campus Universitário, 36570-900 Viçosa-MG, Brazil

\begin{abstract}
The present investigation describes the synthesis of a series of novel triazole derivatives from 4,4'-dihydroxybenzophenone along with their elastase inhibitory activity. The 1,2,3-triazoles were obtained via the copper(I)-catalyzed azide-alkyne cycloaddition reaction (CuAAC), also known as click reaction, between bis(4-(prop-2-yn-1-yloxy))benzophenone and several benzyl azides. It was found that five derivatives exhibited significant inhibitory effects, presenting half maximal inhibitory concentration $\left(\mathrm{IC}_{50}\right)$ values in the range of 16.6 to $72.1 \mu \mathrm{M}$. The most active compound, namely bis(4-(1-(4-iodobenzyl)-1H-1,2,3-triazol-4-yl)methoxy)benzophenone $\left(\mathrm{IC}_{50}=16.6 \pm 1.9 \mu \mathrm{M}\right)$, was found to bind to elastase with the inhibition constant $\left(\mathrm{K}_{\mathrm{i}}\right)$ of $11.12 \mu \mathrm{M}$, thereby illustrating competitive inhibitory behavior. Further, docking investigations provided insights on the possible binding mode of the most active compound with the elastase.
\end{abstract}

Keywords: elastase, serine protease, CuAAC reaction, benzophenone, 1,2,3-triazole

\section{Introduction}

Benzophenones are of chemical, medicinal, and industrial interest. ${ }^{1}$ Several of their derivatives exhibit important biological activities like anticancer, ${ }^{2,3}$ antiviral on $\mathrm{HIV},{ }^{4}$ antibacterial, ${ }^{5}$ activity against Alzheimer's disease, ${ }^{6}$ and anti-inflammatory. ${ }^{7}$

The anti-inflammatory action of benzophenones is well documented in the literature. ${ }^{8}$ For instance, ketoprofen is an example of synthetic benzophenone that has been commercialized as an anti-inflammatory drug. Recently, studies have demonstrated that structural modifications carried out on this drug afforded substances with improved anti-inflammatory activity. ${ }^{9}$ Miyano et al. ${ }^{10}$ synthesized a series of 4-(acyloxy)benzophenones and 4,4'-bis(acyloxy) benzophenones and evaluated their anti-inflammatory

*e-mail: robsonr.teixeira@ufv.br activity using human neutrophil elastase (HNE) as a template. The derivatives 4-(pivaloyloxy)benzophenone and 4-(isobutyryloxy)benzophenone showed elastase inhibitory activity with half maximal inhibitory concentration $\left(\mathrm{IC}_{50}\right)$ of 0.62 and $0.25 \mu \mathrm{M}$, respectively. It was found that 4,4'-bis(acyloxy)benzophenones were more potent than the corresponding 4-(acyloxy)benzophenones, highlighting 4,4'-bis(2,2-dimethylpropanoate)benzophenone with $\mathrm{IC}_{50}=0.12 \mu \mathrm{M}$ and inhibition constant $\left(\mathrm{K}_{\mathrm{i}}\right)=7.1 \times 10^{-8} \mathrm{M}^{10}$

Serine proteases are involved in different branches of the immune system and play an important role in inflammation. In a recent investigation from our research group, Martins et al. ${ }^{11}$ reported in vitro inhibition of serine proteases by synthetic and natural benzophenones, which showed moderate to high inhibitory effects against all the enzymes. Guttiferone A displayed $\mathrm{IC}_{50}$ of $2.7 \pm 0.1 \mu \mathrm{M}$, a value similar to the $\mathrm{IC}_{50}$ of chymostatin $(2.1 \pm 0.1 \mu \mathrm{M})$, a classical inhibitor of serine protease cathepsin G. ${ }^{11}$ 
Molecular hybridization has been shown to be a promising strategy for obtaining new compounds. It is mainly based on the combination of two or more known bioactive pharmacophoric fragments, by appropriate fusion, into a single hybrid molecule. ${ }^{12}$ Ideally, new hybrids are always endowed with improved activity or new biological properties in comparison to their individual components. ${ }^{13}$

Despite being an emerging strategy in the discovery of new drugs, molecular hybridization has recently gained significant attention among the scientific community, with several successful examples already reported in the literature. For example, Mareddy et al. ${ }^{14}$ synthesized a novel series of 1,2,3-triazole-nimesulide hybrids and evaluated their cancer cell growth inhibitory properties against various cancer cell lines including A549 (lung cancer), HepG2 (liver cancer), HeLa (cervical cancer), and DU145 (prostate cancer). Three of the obtained hybrids inhibited the growth $\left(\mathrm{IC}_{50}\right.$ ca. 6-10 $\left.\mu \mathrm{M}\right)$ of A549, HepG2, HeLa, and DU145 cancer cell lines.

Among the various strategies that are currently being used to obtain new drugs through molecular hybridization, click chemistry has been proven to be one of the most promising approaches. It refers to a group of reactions that are regiospecific in nature and can be performed easily, yielding highly pure compounds with fewer efforts. Also, these reactions are very attractive in the discovery and development of new drugs. ${ }^{15}$ Considering the transformations that can be included in the click chemistry universe, the copper(I)-catalyzed 1,3-dipolar cycloaddition of azides and terminal alkynes to form 1,2,3-triazoles (CuAAC reaction) has been explored as an efficient approach to obtain new compounds.

A 1,2,3-triazole ring is an attractive unit, since it is stable to metabolic degradation, oxidative/reducing conditions, and improves solubility by actively binding to biomolecular targets. ${ }^{15}$ This ring is also known as the pharmacophoric group. ${ }^{16}$ In addition, it is present in the structure of important drug such as tazobactam and cefatrizine. ${ }^{17}$

The 1,2,3-triazole functionality has gained tremendous interest of numerous researchers, since compounds containing this structural motif exhibits several biological activities, such as antituberculosis, ${ }^{18}$ anticancer, ${ }^{19,20}$ antibacterial, ${ }^{21,22}$ antioxidant, ${ }^{23,24}$ leishmanicidal, ${ }^{25}$ antifungal, ${ }^{26}$ against Alzheimer's disease, ${ }^{27}$ antimalaria. ${ }^{28,29}$ Several studies have shown the efficacy of triazole as potent elastase inhibitors. ${ }^{30,31}$ For example, Ruivo et al. ${ }^{32}$ synthesized a series of 4-oxo- $\beta$-lactam derivatives coupled to the 1,2,3-triazole functionality. These compounds proved to be potent elastase inhibitors with $\mathrm{IC}_{50}$ values (14 to $103 \mathrm{nM})$ comparable to the $\mathrm{IC}_{50}(15 \mathrm{nM})$ determined for the only elastase inhibitor (ONO-5046) in clinical use. ${ }^{32}$
Our research group has been involved in investigating several synthetic ${ }^{33-37}$ and natural ${ }^{38}$ benzophenones. For instance, the anti-inflammatory potential of 2,2',4-trihydroxybenzophenone was assessed by means of the rat-paw-edema induced by carrageenan application assay. The 2,2',4-trihydroxybenzophenone was capable of inhibiting the inflammatory process, reducing the diameter of the edema by $47.0 \pm 10 \%$ after $2 \mathrm{~h}$, and $34.0 \pm 6 \%$ after 3 h. The 2,2',4-trihydroxybenzophenone showed similar efficacy for inhibition of rat-paw-edema than indomethacin, which inhibited the edematogenic process by $43.0 \pm 4 \%$, $51.0 \pm 7 \%$, and $52.0 \pm 5 \%$ after 2,3 and $4 \mathrm{~h}$, respectively. ${ }^{36}$

As stated above, serine-proteases, such as elastase, play an important role in inflammatory processes. Thus, these enzymes are targeted to explore in the direction of research and development of more effective anti-inflammatory compounds that can be employed in the therapeutic. In the view of developing effective anti-inflammatory compounds, while considering the inhibitory effect of the benzophenones (and their derivatives) ${ }^{39}$ and the compounds containing the 1,2,3-triazole functionalities ${ }^{40,41}$ on serine proteases, here we report the synthesis of a new series of hybrids of 4,4'-dihydroxybenzophenone derivatives containing 1,2,3-triazole moiety (Figure 1). In vitro studies were also performed to evaluate their inhibitory capability on the enzyme elastase.

\section{Results and Discussion}

For the synthesis of 4,4'-dihydroxybenzophenone triazole derivatives, the preparation of several benzyl azides was required. The synthesis of these azides (Figure 2) was carried out from their corresponding benzyl bromides, using procedures described in the literature. ${ }^{42,43}$

The synthesis of the compounds containing triazole rings was performed in two steps as shown in Figure 2. The first step corresponds to the propargylation reaction of 4,4'-dihydroxybenzophenone (1), which produced the terminal alkyne bis(4-(prop-2-yn-1-yloxy))benzophenone (2) in $83 \%$ yield. Next is the key step which involves the synthesis of benzophenone derivatives 4-18 corresponding to the copper(I)-catalyzed azide-alkyne cycloaddition (CuAAC) reaction, also known as click reaction, between the alkynylated compound $\mathbf{2}$ and several benzyl azides. Thus, the triazolic derivatives 4-18 were obtained with yields in the range of $42-70 \%$. All the triazolic compounds were characterized by infrared (IR) and ${ }^{1} \mathrm{H}$ and ${ }^{13} \mathrm{C}$ nuclear magnetic resonance (NMR) spectroscopies as well as highresolution mass spectrometry (HRMS). In the ${ }^{1} \mathrm{H}$ NMR spectra, the hydrogen atoms of methylene groups attached to nitrogen or oxygen were noticed as singlets, while the 
Vol. 30, No. 1, 2019

Dias et al.

99

signal for the hydrogen present in the triazolic rings was observed as singlet within 7.44-8.32 ppm range. The carbon chemical shifts in ${ }^{13} \mathrm{C}$ NMR are compatible with the structures of the compounds. Furthermore, in the IR
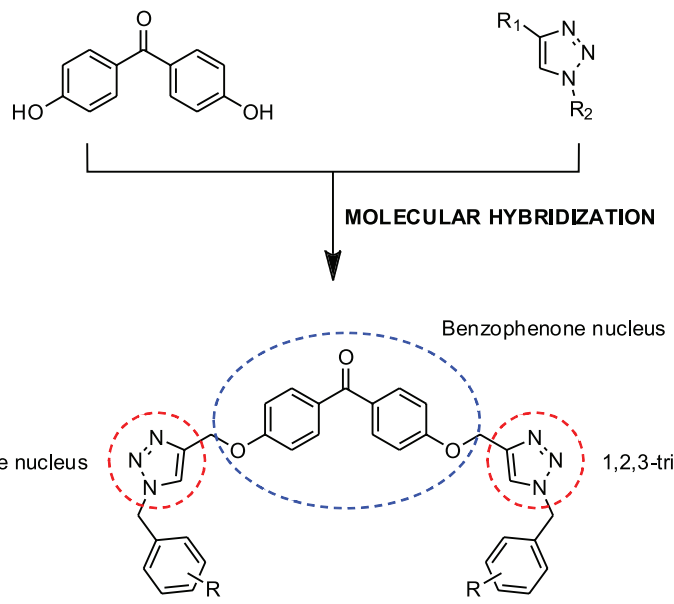

Figure 1. General structure of the derivatives obtained by molecular hybridization.
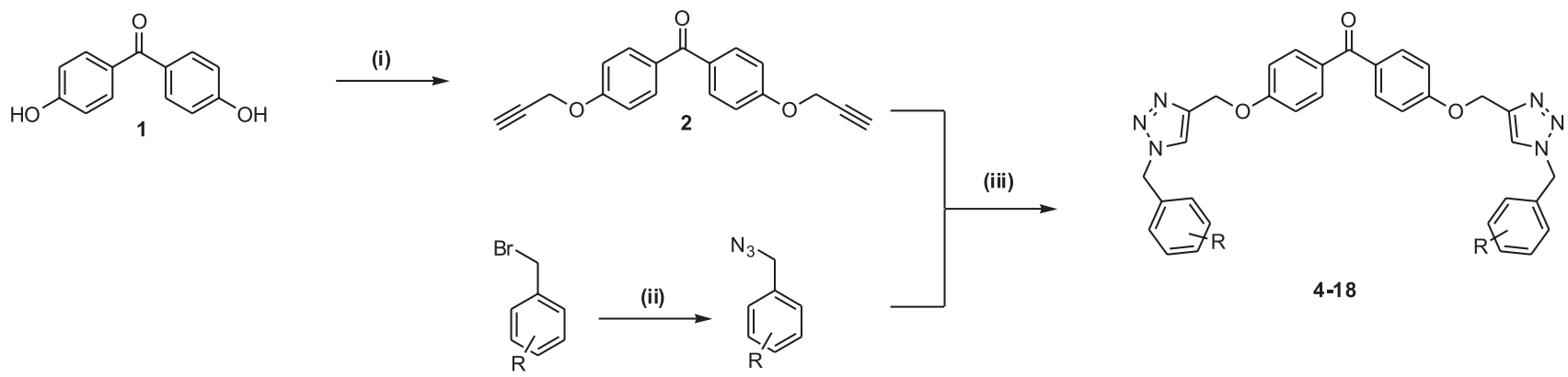

3a-30
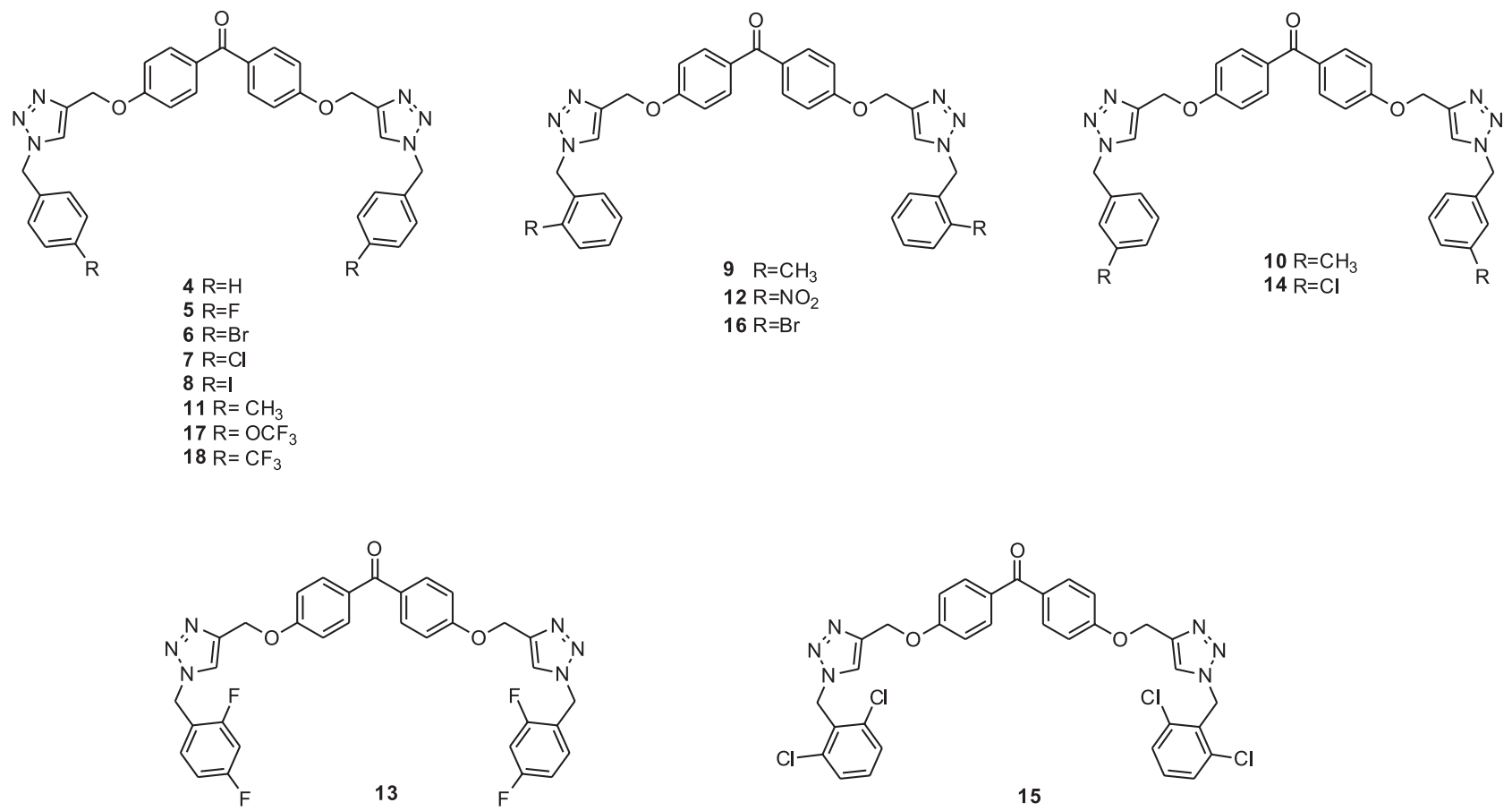

Figure 2. Synthetic steps involved in the preparation of thiazole derivatives of 4,4'-dihydroxybenzophenone. Reagents and conditions: (i) propargyl bromide (2.4 equiv.), $\mathrm{K}_{2} \mathrm{CO}_{3}$ ( 4.0 equiv.), acetone, reflux, $24 \mathrm{~h} ; 83 \%$ yield; (ii) sodium azide ( 4.00 equiv.), DMSO, rt., $2 \mathrm{~h}, 80-90 \%$ yield; (iii) $\mathrm{CuSO}_{4} \cdot 5 \mathrm{H}_{2} \mathrm{O}$ ( 0.40 equiv.), sodium ascorbate ( 0.80 equiv.), DCM/ $\mathrm{H}_{2} \mathrm{O}$ ( $\left.1: 1 \mathrm{v} / \mathrm{v}\right)$, rt., 6 h, $42-70 \%$. 
spectra, expected bands for functional groups were also observed. Finally, the molecular formulas of the triazolic derivatives were confirmed by HRMS analysis.

With the derivatives in hands, their inhibitory effect on elastase was evaluated. Among the sixteen derivatives (2, and 4-18), compounds 5, 7, 8, and 18 showed inhibitory activity on elastase. The $\mathrm{IC}_{50}$ values obtained for these compounds are depicted in Table 1.

Table 1. $\mathrm{IC}_{50}$ values of the inhibitory effect of triazole compounds on elastase

\begin{tabular}{lc}
\hline Compound & $\mathrm{IC}_{50} / \mu \mathrm{M}$ \\
\hline $\mathbf{5}$ & $72.1 \pm 3.1$ \\
$\mathbf{7}$ & $45.7 \pm 4.7$ \\
$\mathbf{8}$ & $16.6 \pm 1.9$ \\
$\mathbf{1 8}$ & $32.7 \pm 0.8$ \\
EGCG & $220.4 \pm 5.7$
\end{tabular}

$\mathrm{IC}_{50}$ : half maximal inhibitory concentration; EGCG: epigallocatechin3-gallate.

Compounds $\mathbf{8}$ and $\mathbf{1 8}$ displayed the best inhibitory effects presenting $\mathrm{IC}_{50}$ of 16.6 and $32.7 \mu \mathrm{M}$, respectively. The positive control epigallocatechin-3-gallate (EGCG) showed an $\mathrm{IC}_{50}$ value of $220.4 \mu \mathrm{M}$. The possible inhibition mechanism exhibited by the most active compound $\mathbf{8}$ was validated by performing a detailed kinetic investigation. The Lineweaver-Burk or double-reciprocal plots, $1 / \mathrm{V}_{0}$ versus $\left.1 / \mathrm{I}\right]$, for compound $\mathbf{8}$ is shown in Figure 3a, where $\mathrm{V}_{0}$ is the initial velocity and $[\mathrm{I}]$ is the inhibitor concentration. The plot of $1 / \mathrm{V}_{0}$ versus $1 /[\mathrm{I}]$ is useful for distinguishing competitive and noncompetitive inhibition modes. Further, inhibition parameters can also be calculated from these plots. ${ }^{44}$ From the plot, it is evident that increasing [I] gives straight lines converging on the $1 / \mathrm{V}_{0}$ axis, having different slopes. This result suggested that compound $\mathbf{8}$ acts as a competitive inhibitor of elastase. ${ }^{44}$

To further confirm the inhibitory activity of compound $\mathbf{8}$, kinetic parameters were calculated from the plot $1 / \mathrm{V}_{0}$ versus $1 /[\mathrm{I}]$ and values obtained are shown in Table 2. $\mathrm{K}_{\mathrm{m}}$ (Michaelis-Menten constant) and $\mathrm{V}_{\max }$ (maximum velocity) were determined at four different concentrations of compound $\mathbf{8}$ (see Table 2). The values listed in Table 2 indicate that compound $\mathbf{8}$ binds to elastase with an inhibition constant $\left(\mathrm{K}_{\mathrm{i}}\right)$ of $11.12 \mu \mathrm{M}$. This type of inhibition occurs when inhibitor (I) compete with an enzyme's substrate for binding to the active site to form an enzyme-inhibitor complex (EI) complex (Figure 3b).

Table 2. Kinetic parameters from elastase inhibition by compound 8 (means \pm standard deviation)

\begin{tabular}{lcccc}
\hline \multirow{2}{*}{ Parameter } & \multicolumn{4}{c}{ Compound 8} \\
\cline { 2 - 5 } & $0 \mu \mathrm{M}$ & $5 \mu \mathrm{M}$ & $10 \mu \mathrm{M}$ & $20 \mu \mathrm{M}$ \\
\hline $\mathrm{V}_{\max } /\left(\mu \mathrm{M} \mathrm{s}^{-1}\right)$ & $17.38 \pm 0.83$ & $16.53 \pm 0.57$ & $16.33 \pm 0.35$ & $17.23 \pm 0.26$ \\
$\mathrm{~K}_{\mathrm{m}} / \mathrm{mM}$ & $0.64 \pm 0.13$ & $0.82 \pm 0.15$ & $1.37 \pm 0.28$ & $1.58 \pm 0.22$ \\
$\alpha$ & \multicolumn{4}{c}{$1.45 \pm 0.16$} \\
$\mathrm{~K}_{\mathrm{i}} / \mu \mathrm{M}$ & \multicolumn{3}{c}{$11.12 \pm 0.32$} \\
\hline
\end{tabular}

$\mathrm{V}_{\max }$ : maximum velocity; $\mathrm{K}_{\mathrm{m}}$ : Michaelis-Menten constant; $\alpha$ : factor by which $\mathrm{K}_{\mathrm{S}}$ changes when compound $\mathbf{8}$ occupies the enzyme; $\mathrm{K}_{\mathrm{i}}$ : inhibitory constant.

Competitive inhibitor modifies $\mathrm{K}_{\mathrm{m}}$ without affecting $\mathrm{V}_{\max }$. By taking compound $\mathbf{8}$ into consideration, it was observed that $\mathrm{K}_{\mathrm{m}}$ values ranged between 0.64 and $1.58 \mathrm{mM}$, while values of $\mathrm{V}_{\max }$ falls in the range of 17.38-17.23 $\mu \mathrm{M} \mathrm{s}^{-1}$. It was further revealed by the analysis of variance (ANOVA) that in presence and absence of compound $\mathbf{8}$ significant differences in $\mathrm{K}_{\mathrm{m}}$ values $(p<0.001)$ were observed, whereas no substantial differences were detected between $\mathrm{V}_{\max }$ values $(p>0.05$ ). In addition, factor $\alpha$ (Table 2 ), the factor

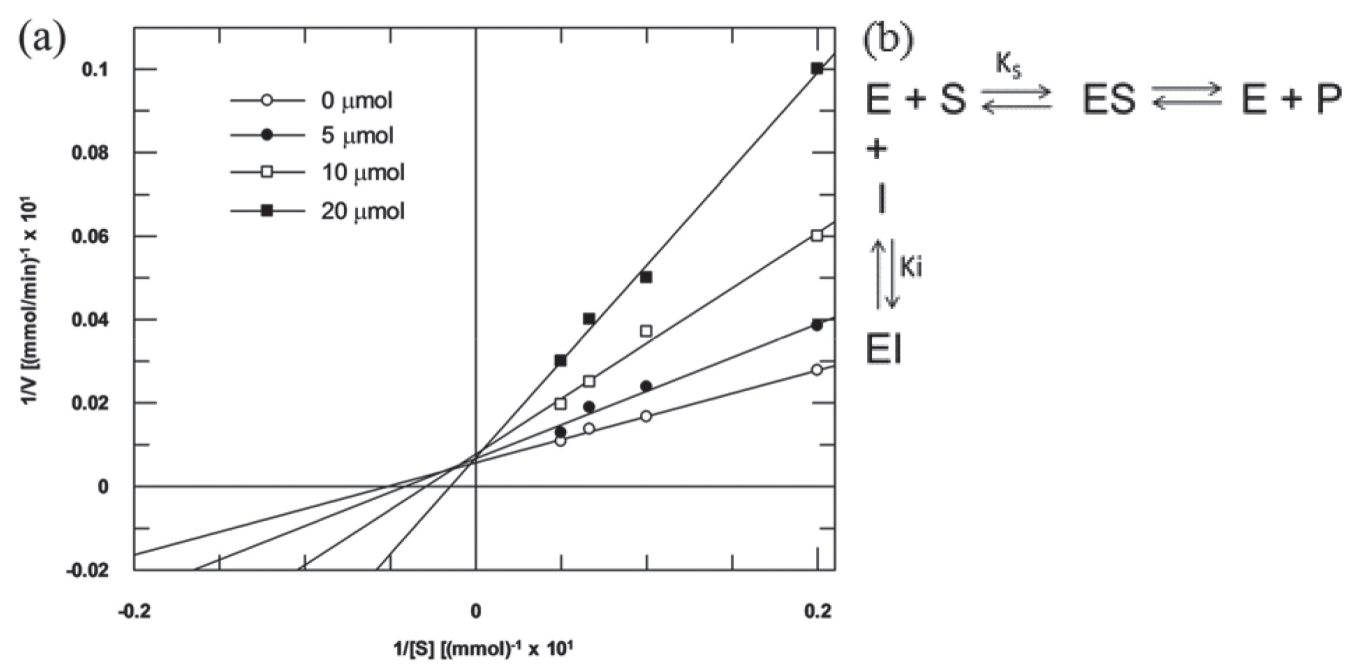

Figure 3. (a) Lineweaver-Burk plot for hydrolysis of suc-A-A-A-pNA by elastase in the presence and absence of compound 8; (b) schematic mechanism of elastase inhibition. E: enzime; S: substrate; P: product; I: inhibitor; $\mathrm{K}_{\mathrm{i}}$ : inhibitory constant; $\mathrm{K}_{\mathrm{S}}$ : dissociation constant of the enzyme-substrate complex. 
by which $\mathrm{K}_{\mathrm{S}}$ (dissociation constant of the enzyme-substrate complex) changes when compound $\mathbf{8}$ occupies the enzyme, was found to be 1.45 .

Molecular docking was performed in order to have deep insight on the inhibitory effect of the synthetic compounds, elucidating a correlation between the biological activity and compound structures. The docking analysis was carried out with sixteen compounds ( 2 and 4-18). As shown in Figure 4a, the docking prediction demonstrated that derivatives $\mathbf{5 - 8}$ and $\mathbf{1 8}$ bind close to the active site of elastase, while the other compounds are more likely to have a higher affinity towards the outer side of the catalytic site.

The results obtained from docking analysis are in strong correlation with the experimental observations, indicating that only compounds $\mathbf{5 , 7 , 8}$ and 18 showed an inhibitory potential towards the enzyme. Thus, four out of five predicted compounds showed the result in relevance to both computational and experimental approaches. Furthermore, the best values of binding affinity with the enzyme suggest that compound $\mathbf{5}$ will have a higher level of activity followed by derivatives $\mathbf{8}$ and $\mathbf{1 8}$ (Figure 4b). (a)

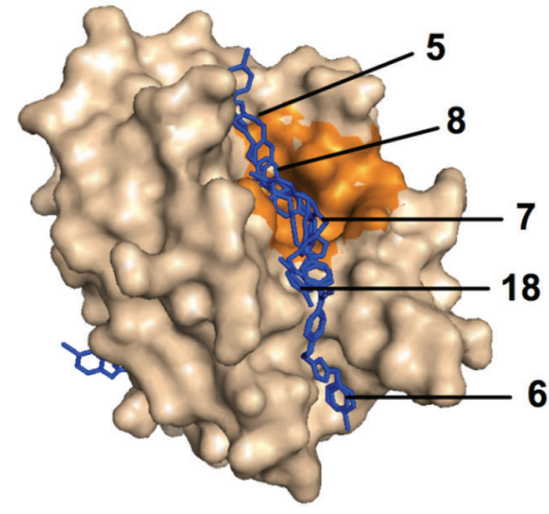

(b)

\begin{tabular}{cc} 
Compound & $\begin{array}{c}\text { Predicted Binding Affinity } \\
\text { (Kcal/mol) }\end{array}$ \\
\hline $\mathbf{5}$ & -9.1 \\
$\mathbf{6}$ & -8.2 \\
$\mathbf{7}$ & -8.7 \\
$\mathbf{8}$ & -9.0 \\
$\mathbf{1 8}$ & -8.9 \\
\hline
\end{tabular}

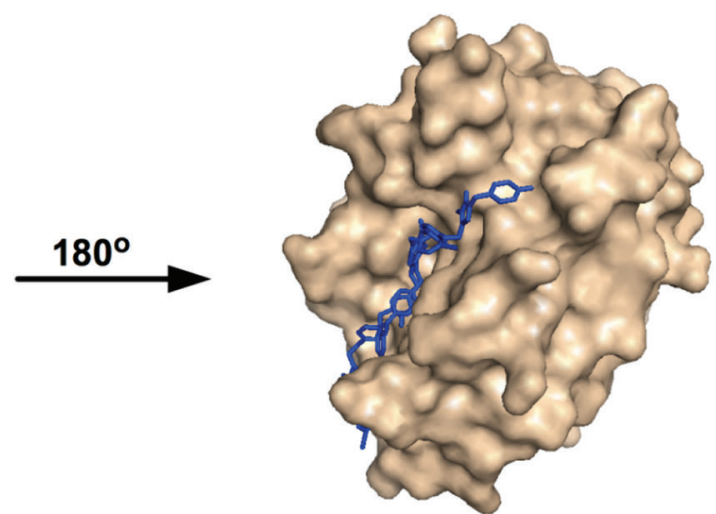

(c)

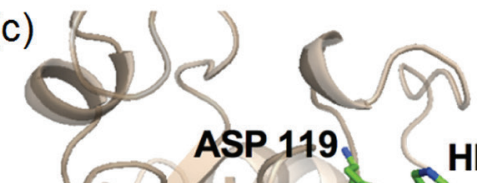

HIS 71

(d)
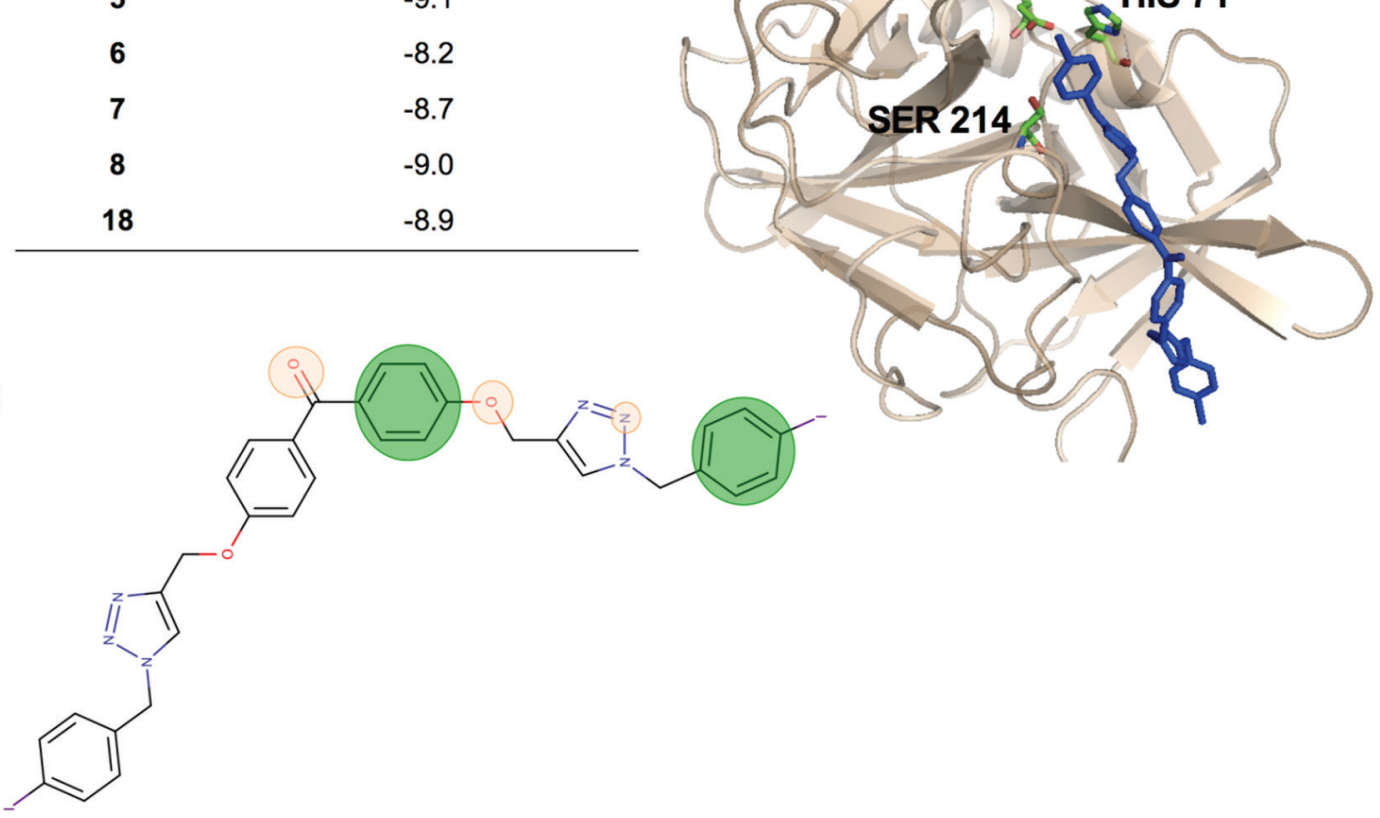

Figure 4. Predicted molecular interactions of the synthetic compounds with elastase. (a) Docking of compounds 2 and 4-18 with elastase (PDB ID: $1 \mathrm{GVK})$. The protein surface structure is shown in beige, the active site is highlighted in orange and the compounds are represented by blue sticks. Only the compounds $\mathbf{5}, \mathbf{6}, \mathbf{7}, \mathbf{8}$ and $\mathbf{1 8}$ were predicted to bind to catalytic site suggesting inhibitory activity by competitive binding. The other compounds showed predicted affinity outside of active site; (b) relative binding affinity calculated for compounds $\mathbf{5 , 6}, \mathbf{7}, \mathbf{8}$ and $\mathbf{1 8}$ with predicted interactions in the enzyme catalytic site; (c) potential interaction of the most active compound $\mathbf{8}$ with catalytic amino acids from elastase protein; (d) pharmacophore mapping of compound $\mathbf{8}$ with hydrogen bound acceptors represented by orange circles and hydrophobic aromatics represented by green circles. 
The above experimental results demonstrated that the compounds $\mathbf{8}$ and $\mathbf{1 8}$ are more active than $\mathbf{5}$, and this difference between docking results and biological assays can be associated with physicochemical characteristics of the compounds, such as solubility and polarity that were not taken into consideration during the molecular docking calculations. The solubility influences the amount of compounds available to interact with the target affecting the protein-to-compound ratio and this parameter has impacted directly the binding constant. ${ }^{45,46}$ Additionally, the entropy and desolvation effects remain as the two major challenging issues for current docking score functions. ${ }^{47}$ Despite these limitations, docking approach showed the correlation with the experimental affinity of four out of five compounds analyzed, and correctly identified compounds with inhibitory activity.

Moreover, docking results predicted that compound $\mathbf{8}$ has potential to interact with catalytic amino acids His71, Asp119, and Ser214 of elastase with a distance of 3.6, 3.1, and $2.2 \AA$, respectively. These residues are considered important as they are directly involved in chemical transformation between the substrate and the elastase. ${ }^{48}$ The majority of the protease inhibitors binds in and blocks access to the active site of their target protease, interacting with the protease subsites and catalytic residues to avoid the catalysis reaction. ${ }^{49}$ In addition, compounds that interact with catalytic residues often exhibit high inhibitory activity, and tend to inhibit many related proteases. ${ }^{50}$ Nevertheless, the interaction also depends on other residues that are not directly involved with catalysis. These residues are highly variable compared to other proteases. Thus, the variability of these amino acids can minimize the effect of crossinhibition with other proteases.

Therefore, the predicted interaction between compound $\mathbf{8}$ and the key amino acids for the catalytic mechanism may also be related to the high inhibition efficacy of this compound as it is observed in the biological assays.

\section{Conclusions}

In summary, a series of sixteen bis-1,2,3-triazole derivatives of 4,4 '-dihydroxybenzophenone was successfully synthesized in yields ranging from $42-70 \%$. The biological assays revealed that compounds 5, 7, 8, and 18 displayed inhibitory effect on elastase proteolytic action. The compound $\mathbf{8}$ proved to be the most active one. Kinetics assays carried out with $\mathbf{8}$ indicated that elastase inhibition occurs by following a competitive mechanism. Molecular docking investigation showed that triazolic derivative $\mathbf{8}$ establishes interactions with aminoacid catalytic site residues which corroborates its activity. These findings may contribute in drug design, thereby indicating that 1,2,3-triazole derivatives of 4,4'-dihydroxybenzophenone can be explored as a scaffold towards the development of new elastase inhibitors.

\section{Experimental}

\section{General}

All reagents and solvents were purchased from SigmaAldrich (St. Louis, MO, USA) and Vetec (Rio de Janeiro, Brazil), and were used without further purification. Analytical thin layer chromatography (TLC) analysis was conducted on aluminum-backed precoated silica gel plates (Macherey-Nagel DC-Fertigfolien ALUGRAM ${ }^{\circledast}$ Xtra SIL G/UV254, Düren, Germany) using different solvent systems. TLC plates were visualized using UV light $(\lambda=254 \mathrm{~nm})$ and potassium permanganate solution.

Flash column chromatography was performed with silica gel (70-230 mesh). ${ }^{1} \mathrm{H}$ and ${ }^{13} \mathrm{C}$ NMR spectra were recorded on a Varian Mercury 300 instrument (Varian, Palo Alto, CA, USA) at 300 and $75 \mathrm{MHz}$, respectively, using $\mathrm{CDCl}_{3}$ or DMSO- $d_{6}$ as solvents.

${ }^{1} \mathrm{H}$ NMR data are presented as follows: chemical shift $(\delta)$ in ppm, multiplicity, number of hydrogens, and $J$ values in hertz $(\mathrm{Hz})$. Multiplicities are shown as the following abbreviations: s (singlet), d (doublet), dd (doublet of doublets), t (triplet), m (multiplet). For fluorine-containing derivatives, the multiplicity of some carbon signals are described along with $J$ values in hertz. Melting points (mp) were recorded on the MQAPF-302 equipment (Microquímica Equipamentos, Palhoça, Santa Catarina, Brazil) and were not corrected. IR spectra were obtained using Varian 660-IR (Varian, Palo Alto, CA, USA) equipped with GladiATR scanning from 4000 to $500 \mathrm{~cm}^{-1}$. The HRMS analysis was performed using the Impact II Brucker UHR-QqTOF (ultra-high resolution quadrupole quadrupole-time of fight) mass spectrometry (Bruker Daltonics, Bremen, Germany). The acquisition software used was Otof Control and Hystar software package (Bruker Daltonics, Bremen, Germany) and equipped with an electrospray source operating in negative ionization mode.

\section{Synthesis}

Synthesis of bis(4-(prop-2-yn-1-yloxy))benzophenone (2)

Potassium carbonate $(3.87 \mathrm{~g}, 28.0 \mathrm{mmol})$ and propargyl bromide $(1.50 \mathrm{~mL})$ were added to a stirred solution of 4,4'-dihydroxybenzophenone (1.50 g, $7.00 \mathrm{mmol})$ in acetone $(50 \mathrm{~mL})$. The reaction mixture was refluxed for $24 \mathrm{~h}$. The reaction was then quenched with ice-water/ $\mathrm{CH}_{2} \mathrm{Cl}_{2}$. The 
phases were separated and the aqueous layer was extracted with ethyl acetate $(3 \times 20 \mathrm{~mL})$. The extracts were combined and the resulting organic layer was washed with brine, dried over anhydrous sodium sulfate, and concentrated under reduced pressure to provide crude compound 2. After purification by silica gel flash column chromatography, eluted with ethyl acetate:dichoromethane:hexane 3:1:3 v/v, compound 2 was obtained as a yellow solid with $83 \%$ yield $(1.68 \mathrm{~g}, 5.79 \mathrm{mmol})$. The structure of compound 2 was supported by the following data. TLC: $\mathrm{Rf}=0.60$ (ethyl acetate:dichoromethane:hexane 3:1:3 v/v); mp 91.3-92.2 ${ }^{\circ} \mathrm{C}$; IR (attenuated total reflection (ATR)) $\mathrm{v}_{\max } / \mathrm{cm}^{-1} 3219,2971,2112,1578,1558,1503,1267$; ${ }^{1} \mathrm{H} \mathrm{NMR}\left(300 \mathrm{MHz}, \mathrm{CDCl}_{3}\right) \delta 2.57$ (s, 2H), 4.77 (s, 4H), 7.05 (d, 4H, $J 8.3 \mathrm{~Hz}), 7.80$ (d, 4H, $J 8.3 \mathrm{~Hz}) ;{ }^{13} \mathrm{C}$ NMR $\left(75 \mathrm{MHz}, \mathrm{CDCl}_{3}\right) \delta 55.9,76.1,76.6,114.4,131.3,132.2$, 160.7, 194.3; HRMS [M + H] $]^{+}$calculated for $\mathrm{C}_{19} \mathrm{H}_{15} \mathrm{O}_{3}$ : 291.1016; found: 291.1016.

\section{General procedure for the synthesis of target compounds 4-18}

A round bottom flask $(50 \mathrm{~mL})$ was charged with bis(4-(prop-2-yn-1-yloxy))benzophenone (2) (1.00 equiv.), benzyl azide (4.00 equiv.), sodium ascorbate (0.800 equiv.), dichloromethane $(1.50 \mathrm{~mL})$, distilled water $(1.50 \mathrm{~mL})$, and $\mathrm{CuSO}_{4} \cdot 5 \mathrm{H}_{2} \mathrm{O}$ ( 0.400 equiv.). The resulting reaction mixture was vigorously stirred at room temperature for $6 \mathrm{~h}$ and the progress of the reaction was monitored by TLC analysis. The reaction was quenched by addition of saturated sodium bicarbonate aqueous solution $(15 \mathrm{~mL})$. The layers were separated and the aqueous phase was extracted with dichloromethane $(3 \times 20 \mathrm{~mL})$. The organic extracts were combined and the resulting organic layer was dried over anhydrous sodium sulfate, filtered, and concentrated under reduced pressure to provide crude compounds. Compounds 4-18 were purified by silica gel flash column chromatography eluted with ethyl acetate:dichoromethane:hexane 3:1:3 v/v. Structures of the synthesized compounds were supported by the following data.

\section{Bis(4-(1-benzyl-1H-1,2,3-triazol-4-yl)methoxy) benzophenone (4)}

Yield: 66\% (0.190 g, $0.269 \mathrm{mmol})$; white solid; mp 144-145 ${ }^{\circ} \mathrm{C}$; TLC: $\mathrm{Rf}=0.18$ (ethyl acetate:dichoromethane:hexane 3:1:3 v/v); IR (ATR) $\mathrm{v}_{\max } / \mathrm{cm}^{-1} 3091,2159,2017,1639,1559,1506,1247$; ${ }^{1} \mathrm{H} \mathrm{NMR}\left(300 \mathrm{MHz}, \mathrm{CDCl}_{3}\right) \delta 5.25$ (s, 2H), $5.54(\mathrm{~s}, 4 \mathrm{H})$, 7.02 (d, 4H, J 8.4 Hz), 7.26-7.38 (m, 10H), 7.56 (s, 2H), 7.75 (d, 4H, J 8.4 Hz); ${ }^{13} \mathrm{C} \mathrm{NMR}\left(75 \mathrm{MHz}, \mathrm{CDCl}_{3}\right) \delta 54.3$, $62.1,114.2,122.8,128.1,128.9,129.2,131.1,132.2$,
134.2, 143.9, 161.4, 194.3; HRMS $[\mathrm{M}+\mathrm{H}]^{+}$calculated for $\mathrm{C}_{33} \mathrm{H}_{29} \mathrm{~N}_{6} \mathrm{O}_{3}: 557.2296$, found: 557.2322.

Bis(4-(1-(4-fluorobenzyl)-1H-1,2,3-triazol-4-yl)methoxy) benzophenone (5)

Yield: $65 \%$ (0.190 g, $0.303 \mathrm{mmol})$; white solid; mp 139-140 ${ }^{\circ} \mathrm{C}$; TLC: Rf $=0.10$ (ethyl acetate:dichoromethane:hexane $3: 1: 3 \mathrm{v} / \mathrm{v})$; IR (ATR) $\mathrm{v}_{\max } / \mathrm{cm}^{-1} 3137,1639,1599,1225 ;{ }^{1} \mathrm{H}$ NMR $(300 \mathrm{MHz}$, $\left.\mathrm{CDCl}_{3}\right) \delta 5.25(\mathrm{~s}, 4 \mathrm{H}), 5.51(\mathrm{~s}, 4 \mathrm{H}), 7.03(\mathrm{t}, 4 \mathrm{H}, J 8.7 \mathrm{~Hz})$, 7.09 (s, 4H), 7.25-7.30 (m, 4H), $7.56(\mathrm{~s}, 2 \mathrm{H}), 7.74(\mathrm{~d}, 4 \mathrm{H}$, $J 8.7 \mathrm{~Hz}) ;{ }^{13} \mathrm{C} \mathrm{NMR}\left(75 \mathrm{MHz}, \mathrm{CDCl}_{3}\right) \delta 53.5,62.1,114.2$, 116.2 (d, J 21.5 Hz), 122.7, 130.2 (d, J 3.2 Hz), 130.4 (d, $J 8.5 \mathrm{~Hz}$ ), 131.0, 132.2, 144.0, 161.4, 162.9 (q, J246.9 Hz), 194.3; HRMS $[\mathrm{M}+\mathrm{H}]^{+}$calculated for $\mathrm{C}_{33} \mathrm{H}_{27} \mathrm{~F}_{2} \mathrm{~N}_{6} \mathrm{O}_{3}$ : 593.2107, found: 593.2109.

Bis(4-(1-(4-chlorobenzyl)-1H-1,2,3-triazol-4-yl)methoxy) benzophenone (6)

Yield: $53 \%(0.170 \mathrm{~g}, 0.272 \mathrm{mmol})$; white solid; mp 163-164 ${ }^{\circ} \mathrm{C}$; TLC: Rf $=0.10$ (ethyl acetate:dichoromethane:hexane 3:1:3 v/v); IR (ATR) $v_{\max } / \mathrm{cm}^{-1} 3158,2935,2364,1978,1638,1600,1249$; ${ }^{1} \mathrm{H}$ NMR $\left(300 \mathrm{MHz} \mathrm{CDCl}_{3}\right) \delta 5.25(\mathrm{~s}, 4 \mathrm{H}), 5.51(\mathrm{~s}, 4 \mathrm{H})$, 7.02 (dd, 4H, J 9.0, 2.3 Hz), 7.22 (dd, 4H, J 8.7, 2.2 Hz), 7.35 (dd, 4H, J 8.7, 2.2 Hz), 7.57 (s, 2H), 7.77 (dd, 4H, $J$ 9.0, $2.3 \mathrm{~Hz}) ;{ }^{13} \mathrm{C} \mathrm{NMR}\left(75 \mathrm{MHz}, \mathrm{CDCl}_{3}\right) \delta 53.6,62.0$, $114.2,122.7,129.4,129.5,131.1,132.2,132.8,134.9$, 144.1, 161.4, 194.3; HRMS [M + H] ${ }^{+}$calculated for $\mathrm{C}_{33} \mathrm{H}_{27} \mathrm{Cl}_{2} \mathrm{~N}_{6} \mathrm{O}_{3}$ : 625.1516, found: 625.1513.

Bis(4-(1-(4-bromobenzyl)-1H-1,2,3-triazol-4-yl)methoxy) benzophenone (7)

Yield: $71 \%(0.248 \mathrm{~g}, 0.347 \mathrm{mmol})$; white solid; mp 182-183 ${ }^{\circ} \mathrm{C}$; TLC: $\mathrm{Rf}=0.13$ (ethyl acetate:dichoromethane:hexane 3:1:3 v/v); IR (ATR) $v_{\max } / \mathrm{cm}^{-1} 3158,2935,2360,1982,1638,1600,1225$; ${ }^{1} \mathrm{H}$ NMR (300 MHz, DMSO- $\left.d_{6}\right) \delta 5.24$ (s, 4H), 5.60 (s, 4H), 7.16 (d, 4H, J 8.7 Hz), 7.27 (d, 4H, J 8.1 Hz), 7.57 (d, 4H, $J 8.1 \mathrm{~Hz}), 7.57(\mathrm{~s}, 2 \mathrm{H}), 7.69(\mathrm{~d}, J 8.7 \mathrm{~Hz}) ;{ }^{13} \mathrm{C} \mathrm{NMR}(75 \mathrm{MHz}$, DMSO- $\left.d_{6}\right) \delta 53.6,62.1,114.3,121.9,125.4,130.6,130.7$, 132.2, 132.3, 135.8, 143.0, 161.7, 194.6; HRMS [M + H] ${ }^{+}$ calculated for $\mathrm{C}_{33} \mathrm{H}_{27} \mathrm{Br}_{2} \mathrm{~N}_{6} \mathrm{O}_{3}: 713.0506$, found: 713.0515 .

Bis(4-(1-(4-iodobenzyl)-1H-1,2,3-triazol-4-yl)methoxy) benzophenone (8)

Yield: $42 \%$ (0.055 g, $0.062 \mathrm{mmol})$; white solid; mp 190-191 ${ }^{\circ} \mathrm{C}$; TLC: $\mathrm{Rf}=0.18$ (ethyl acetate:dichoromethane:hexane 3:1:3 v/v); IR (ATR) $v_{\max } / \mathrm{cm}^{-1} 3102,2163,1734,1634,1601,1582,1278$; ${ }^{1} \mathrm{H}$ NMR (300 MHz, DMSO- $\left.d_{6}\right) \delta 5.25$ (s, 4H), $5.58(\mathrm{~s}, 4 \mathrm{H})$, 
$7.12(\mathrm{~d}, 4 \mathrm{H}, J 8.1 \mathrm{~Hz}), 7.17$ (d, 4H, J 8.6 Hz), 7.67 (d, 4H, $J 8.6 \mathrm{~Hz}), 7.74(\mathrm{~d}, 4 \mathrm{H}, J 8.1 \mathrm{~Hz}), 8.32(\mathrm{~s}, 2 \mathrm{H}) ;{ }^{13} \mathrm{C} \mathrm{NMR}$ $\left(75 \mathrm{MHz}\right.$, DMSO- $\left.d_{6}\right) \delta 52.7,61.8,94.9,114.9,125.4,130.6$, 130.7, 132.2, 136.2, 138.0, 142.9, 161.7, 193.6; HRMS $[\mathrm{M}+\mathrm{Na}]^{+}$calculated for $\mathrm{C}_{33} \mathrm{H}_{27} \mathrm{I}_{2} \mathrm{~N}_{6} \mathrm{O}_{3}: 809.0228$, found: 809.0202 .

Bis(4-(1-(2-methylbenzyl)-1H-1,2,3-triazol-4-yl)methoxy) benzophenone (9)

Yield: $55 \%(0.165 \mathrm{~g}, 0.282 \mathrm{mmol})$; white solid; $\mathrm{mp} 186-187{ }^{\circ} \mathrm{C}$; $\mathrm{TLC}: \mathrm{Rf}=0.32$ (ethyl acetate:dichoromethane:hexane 3:1:3 v/v); IR (ATR) $v_{\max } / \mathrm{cm}^{-1} 3099,2921,1970,1639,1601,1258 ;{ }^{1} \mathrm{H}$ NMR $\left(300 \mathrm{MHz}, \mathrm{CDCl}_{3}\right) \delta 2.28(\mathrm{~s}, 6 \mathrm{H}), 5.24(\mathrm{~s}, 4 \mathrm{H}), 5.56(\mathrm{~s}$, 4H), $7.02(\mathrm{~d}, 4 \mathrm{H}, J 8.4 \mathrm{~Hz}), 7.20-7.33(\mathrm{~m}, 8 \mathrm{H}), 7.44(\mathrm{~s}$, $2 \mathrm{H}), 7.75(\mathrm{~d}, 4 \mathrm{H}, J 8.4 \mathrm{~Hz}) ;{ }^{13} \mathrm{C} \mathrm{NMR}\left(75 \mathrm{MHz}, \mathrm{CDCl}_{3}\right) \delta$ 18.9, 52.5, 62.1, 114.3, 122.6, 126.7, 129.3, 129.5, 131.0, 131.1, 132.2, 136.9, 143.7, 161.4, 194.3; HRMS [M + H] calculated for $\mathrm{C}_{35} \mathrm{H}_{33} \mathrm{~N}_{6} \mathrm{O}_{3}: 585.2609$, found: 585.2609.

$\operatorname{Bis}(4-(1-(3-m e t h y l b e n z y l)-1 H-1,2,3-t r i a z o l-4-y l) m e t h o x y)$ benzophenone (10)

Yield: $42 \%$ (0.126 g, $0.215 \mathrm{mmol})$; white solid; mp 130-131 ${ }^{\circ} \mathrm{C}$; TLC $\mathrm{Rf}=0.25$ (ethyl acetate:dichoromethane:hexane 3:1:3 v/v); IR (ATR) $v_{\max } / \mathrm{cm}^{-1} 3122,2944,2165,1976,1640,1596,1236$; ${ }^{1} \mathrm{H}$ NMR (300 MHz, $\left.\mathrm{CDCl}_{3}\right) \delta 2.34$ (s, 6H), $5.25(\mathrm{~s}, 4 \mathrm{H})$, $5.50(\mathrm{~s}, 4 \mathrm{H}), 7.02(\mathrm{~d}, 4 \mathrm{H}, J 8.7 \mathrm{~Hz}), 7.06-7.09(\mathrm{~m}, 4 \mathrm{H})$, $7.17(\mathrm{~d}, 2 \mathrm{H}, J 7.5 \mathrm{~Hz}), 7.26$ (t, 2H, J 8.4 Hz), 7.56 (s, 2H), $7.75(\mathrm{~d}, 4 \mathrm{H}, J 8.7 \mathrm{~Hz}) ;{ }^{13} \mathrm{C}$ NMR $\left(75 \mathrm{MHz}, \mathrm{CDCl}_{3}\right) \delta 21.3$, 54.3, 62.1, 114.2, 122.7, 125.2, 128.9, 129.0, 129.6, 131.1, 132.2, 134.2, 139.0, 143.8, 161.4, 194.3; HRMS [M + H] calculated for $\mathrm{C}_{35} \mathrm{H}_{33} \mathrm{~N}_{6} \mathrm{O}_{3}: 585.2609$, found: 585.2600.

\section{Bis(4-(1-(4-methylbenzyl)-1H-1,2,3-triazol-4-yl)methoxy)} benzophenone (11)

Yield: $59 \%(0.177 \mathrm{~g}, 0.302 \mathrm{mmol})$; white solid; $\mathrm{mp}$ 134-135 ${ }^{\circ} \mathrm{C}$; TLC $\mathrm{Rf}=0.18$ (ethyl acetate:dichoromethane:hexane 3:1:3 v/v); IR (ATR) $v_{\max } / \mathrm{cm}^{-1} 3031,2917,2364,2022,1976,1640,1599$, 1246; ${ }^{1} \mathrm{H}$ NMR $\left(300 \mathrm{MHz}, \mathrm{CDCl}_{3}\right) \delta 2.35(\mathrm{~s}, 6 \mathrm{H}), 5.24$ (s, 4H), 5.49 (s, 4H), $7.02(\mathrm{~d}, 4 \mathrm{H}, J 8.1 \mathrm{~Hz}), 7.20(\mathrm{~s}, 4 \mathrm{H})$, $7.53(\mathrm{~s}, 2 \mathrm{H}), 7.75(\mathrm{~d}, 4 \mathrm{H}, J 8.1 \mathrm{~Hz}) ;{ }^{13} \mathrm{C}$ NMR $(75 \mathrm{MHz}$, $\left.\mathrm{CDCl}_{3}\right) \delta 21.2,54.1,62.1,114.2,122.7,128.2,129.8,131.0$, 131.3, 132.2, 138.9, 143.8, 161.4, 194.3; HRMS [M + H] $]^{+}$ calculated for $\mathrm{C}_{35} \mathrm{H}_{33} \mathrm{~N}_{6} \mathrm{O}_{3}: 585.2609$, found: 585.2604.

Bis(4-(1-(3-nitrobenzyl)-1H-1,2,3-triazol-4-yl)methoxy) benzophenone (12)

Yield: $54 \%(0.181 \mathrm{~g}, 0.280 \mathrm{mmol})$; white solid; $\mathrm{mp} 171-172{ }^{\circ} \mathrm{C}$; TLC: $\mathrm{Rf}=0.10$ (ethyl acetate:dichoromethane:hexane 3:1:3 v/v); IR (ATR) $v_{\max } / \mathrm{cm}^{-1} 3101,2351,1976,1642,1599,1528,1246$; ${ }^{1} \mathrm{H}$ NMR $\left(300 \mathrm{MHz}, \mathrm{CDCl}_{3}\right) \delta 5.30(\mathrm{~s}, 4 \mathrm{H}), 5.66(\mathrm{~s}, 4 \mathrm{H})$, $7.03(\mathrm{~d}, 4 \mathrm{H}, J 8.7 \mathrm{~Hz}), 7.56-7.61(\mathrm{~m}, 4 \mathrm{H}), 7.67(\mathrm{~s}, 2 \mathrm{H})$, $7.76(\mathrm{~d}, 4 \mathrm{H}, J 8.7 \mathrm{~Hz}), 8.17$ (s, 2H), 8.24 (d, 4H, J 7.2 Hz); ${ }^{13} \mathrm{C}$ NMR $\left(75 \mathrm{MHz}, \mathrm{CDCl}_{3}\right) \delta 53.3,62.0,114.3,122.9$, 123.9, 130.4, 131.2, 132.2, 133.9, 136.4, 144.5, 148.6, 161.4, 194.3; HRMS $[\mathrm{M}+\mathrm{H}]^{+}$calculated for $\mathrm{C}_{33} \mathrm{H}_{27} \mathrm{~N}_{8} \mathrm{O}_{7}$ : 647.1997, found: 647.1995 .

Bis(4-(1-(2,4-difluorobenzyl)-1H-1,2,3-triazol-4-yl)methoxy) benzophenone (13)

Yield: 57\% (0.185 g, $0.294 \mathrm{mmol}$ ); white solid; mp 180$181{ }^{\circ} \mathrm{C} ; \mathrm{TLC}: \mathrm{Rf}=0.10$ (ethyl acetate: dichoromethane:hexane $3: 1: 3 \mathrm{v} / \mathrm{v})$; IR (ATR) $v_{\max } / \mathrm{cm}^{-1} 3140,2886,2009,1978$, $1638,1600,1259 ;{ }^{1} \mathrm{H}$ NMR $\left(300 \mathrm{MHz}, \mathrm{CDCl}_{3}\right) \delta 5.26$ (s, $4 \mathrm{H}), 5.56(\mathrm{~s}, 4 \mathrm{H}), 6.85-6.92(\mathrm{~m}, 4 \mathrm{H}), 7.03(\mathrm{~d}, 4 \mathrm{H}, J 8.7 \mathrm{~Hz})$, 7.26-7.36 (m, 2H), $7.70(\mathrm{~s}, 2 \mathrm{H}), 7.76(\mathrm{~d}, 4 \mathrm{H}, J 8.7 \mathrm{~Hz})$; ${ }^{13} \mathrm{C} \mathrm{NMR}\left(75 \mathrm{MHz}, \mathrm{CDCl}_{3}\right) \delta 47.3(\mathrm{~d}, J 3.8 \mathrm{~Hz}), 62.0,104.5$ (t, $J 25.2 \mathrm{~Hz}), 112.2(\mathrm{dd}, J 21.5,3.8 \mathrm{~Hz}), 114.2,117.8(\mathrm{dd}$, $J$ 14.9, $3.8 \mathrm{~Hz}), 122.8,131.1,131.8$ (dd, $J$ 9.9, $4.8 \mathrm{~Hz})$, 132.2, 144.0, 161.4, 162.1 (dd, $J$ 52.1, $12.0 \mathrm{~Hz}$ ), 194.3. HRMS $[\mathrm{M}+\mathrm{H}]^{+}$calculated for $\mathrm{C}_{33} \mathrm{H}_{25} \mathrm{~F}_{4} \mathrm{~N}_{6} \mathrm{O}_{3}: 629.1919$, found: 629.1911 .

Bis(4-(1-(2-chlorobenzyl)-1H-1,2,3-triazol-4-yl)methoxy) benzophenone (14)

Yield: $60 \%(0.193 \mathrm{~g}, 0.310 \mathrm{mmol})$; white solid; mp 176-177 ${ }^{\circ} \mathrm{C}$; TLC: $\mathrm{Rf}=0.21$ (ethyl acetate:dichoromethane:hexane 3:1:3 v/v); IR (ATR) $v_{\max } / \mathrm{cm}^{-1} 3098,2943,1970,1640,1599,1257 ;{ }^{1} \mathrm{H}$ NMR $\left(300 \mathrm{MHz}, \mathrm{CDCl}_{3}\right) \delta 5.27(\mathrm{~s}, 4 \mathrm{H}), 5.68(\mathrm{~s}, 4 \mathrm{H}), 7.03(\mathrm{~d}$, $4 \mathrm{H}, J 8.7 \mathrm{~Hz}), 7.21-7.34(\mathrm{~m}, 6 \mathrm{H}), 7.43(\mathrm{~d}, 2 \mathrm{H}, J 8.7 \mathrm{~Hz})$, $7.67(\mathrm{~s}, 2 \mathrm{H}), 7.75(\mathrm{~d}, 4 \mathrm{H}, J 8.7 \mathrm{~Hz}) ;{ }^{13} \mathrm{C}$ NMR $(75 \mathrm{MHz}$, $\left.\mathrm{CDCl}_{3}\right) \delta 51.5,62.0,114.3,123.1,127.6,129.9,130.4$, 130.5, 131.1, 132.2, 132.2, 133.5, 143.8, 161.4, 194.3; HRMS $[\mathrm{M}+\mathrm{H}]^{+}$calculated for $\mathrm{C}_{33} \mathrm{H}_{27} \mathrm{Cl}_{2} \mathrm{~N}_{6} \mathrm{O}_{3}: 625.1516$, found: 625.1505 .

Bis(4-(1-(2,6-dichlorobenzyl)-1H-1,2,3-triazol-4-yl)methoxy) benzophenone (15)

Yield: $57 \%(0.204 \mathrm{~g}, 0.294 \mathrm{mmol})$; white solid; mp 187-188 ${ }^{\circ} \mathrm{C}$; TLC: $\mathrm{Rf}=0.33$ (ethyl acetate:dichoromethane:hexane 3:1:3 v/v); IR (ATR) $v_{\max } / \mathrm{cm}^{-1} 3094,2354,1976,1642,1600,1256 ;{ }^{1} \mathrm{H}$ NMR $\left(300 \mathrm{MHz}, \mathrm{CDCl}_{3}\right) \delta 5.24(\mathrm{~s}, 4 \mathrm{H}), 5.87(\mathrm{~s}, 4 \mathrm{H}), 7.03(\mathrm{~d}$, $4 \mathrm{H}, J 8.7 \mathrm{~Hz}), 7.25-7.33(\mathrm{~m}, 2 \mathrm{H}), 7.41(\mathrm{~d}, J 8.1 \mathrm{~Hz}), 7.62$ (s, 2H), $7.75(\mathrm{~d}, 4 \mathrm{H}, J 8.7 \mathrm{~Hz}) ;{ }^{13} \mathrm{C} \mathrm{NMR}\left(75 \mathrm{MHz}, \mathrm{CDCl}_{3}\right.$ ) $\delta 49.1,62.1,114.3,122.7,128.9,129.9,131.1,131.2,132.2$, 136.8, 143.4, 161.4, 194.3; HRMS [M + H] ${ }^{+}$calculated for $\mathrm{C}_{33} \mathrm{H}_{24} \mathrm{Cl}_{4} \mathrm{~N}_{6} \mathrm{NaO}_{3}:$ 717.3833, found: 717.0584 . 
$\operatorname{Bis(4-(1-(2-bromobenzyl)-1H-1,2,3-triazol-4-yl)methoxy)~}$ benzophenone (16)

Yield: $51 \%(0.295 \mathrm{~g}, 0.413 \mathrm{mmol})$; white solid; $\mathrm{mp}$ 166-167 ${ }^{\circ} \mathrm{C}$; TLC: $\mathrm{Rf}=0.24$ (ethyl acetate:dichoromethane:hexane 3:1:3 v/v); IR (ATR) $v_{\max } / \mathrm{cm}^{-1}$ 3096, 2366, 1976, 1640, 1596, 1232; ${ }^{1} \mathrm{H}$ NMR $\left(300 \mathrm{MHz}, \mathrm{CDCl}_{3}\right) \delta 5.28(\mathrm{~s}, 4 \mathrm{H}), 5.68(\mathrm{~s}, 4 \mathrm{H}), 7.03(\mathrm{~d}, 4 \mathrm{H}$, $J$ 8.1 Hz), 7.20-7.29 (m, 6H), $7.33(\mathrm{~d}, 2 \mathrm{H}, J 7.8 \mathrm{~Hz}), 7.68$ (s, 2H), $7.64(\mathrm{~d}, 4 \mathrm{H}, J 8.1 \mathrm{~Hz}) ;{ }^{13} \mathrm{C}$ NMR $\left(75 \mathrm{MHz}, \mathrm{CDCl}_{3}\right)$ $\delta$ 53.9, 62.1, 114.3, 123.1, 123.5, 128.3, 130.4, 130.5, 131.1, 132.2, 133.3, 133.9, 143.8, 161.4, 194.3; HRMS $[\mathrm{M}+\mathrm{H}]^{+}$ calculated for $\mathrm{C}_{33} \mathrm{H}_{26} \mathrm{Br}_{2} \mathrm{~N}_{6} \mathrm{NaO}_{3}:$ : 737.3952, found: 737.0310.

Bis(4-((1-(4-trifluoromethoxy)benzyl)-1H-1,2,3-triazol-4-yl) methoxy)benzophenone (17)

Yield: $58 \%(0.100 \mathrm{~g}, 0.139 \mathrm{mmol})$; white solid; mp 178-179 ${ }^{\circ} \mathrm{C}$; TLC: $\mathrm{Rf}=0.11$ (ethyl acetate:dichoromethane:hexane 3:1:3 v/v); IR (ATR) $v_{\max } / \mathrm{cm}^{-1} 3131,2186,1976,1640,1600,1251 ;{ }^{1} \mathrm{H}$ NMR $\left(300 \mathrm{MHz}, \mathrm{CDCl}_{3}\right) \delta 5.27(\mathrm{~s}, 4 \mathrm{H}), 5.61(\mathrm{~s}, 4 \mathrm{H}), 7.02(\mathrm{~d}$, $J 8.7 \mathrm{~Hz}), 7.38(\mathrm{~d}, 4 \mathrm{H}, J 8.4 \mathrm{~Hz}), 7.63(\mathrm{~d}, 6 \mathrm{H}, J 9.6 \mathrm{~Hz}), 7.75$ $(\mathrm{d}, 4 \mathrm{H}, J 8.4 \mathrm{~Hz}) ;{ }^{13} \mathrm{C} \mathrm{NMR}\left(75 \mathrm{MHz}, \mathrm{CDCl}_{3}\right) \delta 53.6,62.0$, 114.2, 122.9, 123.7 (q, $J 270.8 \mathrm{~Hz}), 126.2(\mathrm{q}, J 7.5 \mathrm{~Hz}$ ), 128.3, 131.1 (q, $J 18.6 \mathrm{~Hz}), 132.2,138.3,144.3,161.3$, 194.3; HRMS $[\mathrm{M}+\mathrm{H}]^{+}$calculated for $\mathrm{C}_{35} \mathrm{H}_{27} \mathrm{~F}_{6} \mathrm{~N}_{6} \mathrm{O}_{5}$ : 725.1942, found: 725.1936 .

Bis(4-((1-(4-trifluoromethyl)benzyl)-1H-1,2,3-triazol-4-yl) methoxy)benzophenone (18)

Yield: $58 \%(0.209 \mathrm{~g}, 0.302 \mathrm{mmol})$; white solid; mp 161-162 ${ }^{\circ} \mathrm{C}$; TLC: $\mathrm{Rf}=0.13$ (ethyl acetate:dichoromethane:hexane $3: 1: 3 \mathrm{v} / \mathrm{v}$ ); IR (ATR) $v_{\max } / \mathrm{cm}^{-1} 3109,2608,1605,1598,1246 ;{ }^{1} \mathrm{H}$ NMR $\left(300 \mathrm{MHz}, \mathrm{CDCl}_{3}\right) \delta 5.27(\mathrm{~s}, 4 \mathrm{H}), 5.53(\mathrm{~s}, 4 \mathrm{H}), 7.03(\mathrm{~d}, 4 \mathrm{H}$, $J 7.8 \mathrm{~Hz}), 7.23(\mathrm{~d}, 4 \mathrm{H}, J 8.3 \mathrm{~Hz}), 7.32(\mathrm{~d}, 4 \mathrm{H}, J 8.3 \mathrm{~Hz})$, 7.60 (s, 2H), 7.76 (d, 4H, J 7.8 Hz); ${ }^{13} \mathrm{C}$ NMR $(75 \mathrm{MHz}$, $\left.\mathrm{CDCl}_{3}\right) \delta 53.4,62.0,114.2,120.3(\mathrm{q}, J 256.5 \mathrm{~Hz}), 121.6$, 122.8, 129.6, 131.1, 132.2, 133.0, 144.2, 149.5, 161.4, 194.3; HRMS [M + H] $]^{+}$calculated for $\mathrm{C}_{35} \mathrm{H}_{27} \mathrm{~F}_{6} \mathrm{~N}_{6} \mathrm{O}_{3}$ : 693.2043, found: 693.2024.

\section{Biological assays}

Elastase from porcine pancreas (Enzyme Commission (EC) No. 3.4.21.36, $\geq 4 \mathrm{U} \mathrm{mg}^{-1}$ ) and $N$-succinyl-ala-alaala- $p$-nitroanilide were purchased from Sigma-Aldrich (St. Louis, MO, USA). The reactions were performed in 96-well plates and all data were collected in triplicate.

Statistical analysis was performed by one-way analysis of variance (ANOVA) followed by the Tukey's test $(p<0.05$ was considered significant).
Kinetic measurements

In order to measure the inhibition parameters, final concentrations of $10 \mathrm{mg} \mathrm{mL}^{-1}$ of elastase was incubated with compounds with increasing concentrations (final concentrations were $1,2,4,8,12$ and $20 \mu \mathrm{M}$ ) in a final volume of $1 \mathrm{~mL}$ using sodium phosfate buffer $(50 \mathrm{mM}$, $\mathrm{pH} 8$ ) containing $100 \mu \mathrm{L}$ of DMSO at $25{ }^{\circ} \mathrm{C}$. After $30 \mathrm{~min}$ of incubation, hydrolytic activity was assayed in a V-M5 Bel Photonics spectrophotometer (Piracicaba, São Paulo, Brazil), mixing compounds derived from 4,4'-dihydroxybenzophenone and elastase by growing concentrations of chromogenic substrate (1-20 mM) in a cuvette of $1 \mathrm{~mL}$. The hydrolysis of chromogenic substrates was monitored at a wavelength of $410 \mathrm{~nm}$ for $5 \mathrm{~min}$. $\mathrm{IC}_{50}$ values, the inhibitor concentration which inhibits 50\% of the enzyme activity, were determined from plots of inhibition percentage versus log inhibitor concentration and calculated by nonlinear regression using the GraFit program. ${ }^{51}$ This software was also used to calculate $K_{m}$ and $\mathrm{V}_{\max }$ values by nonlinear regression. Factor $\alpha$ and $\mathrm{K}_{\mathrm{i}}$ for compound $\mathbf{8}$ were calculated using equation 1, which describes a linear partial competitive inhibition. ${ }^{44}$

$\frac{1}{\mathrm{~V}_{\mathrm{o}}}=\frac{\alpha \mathrm{K}_{\mathrm{M}}}{\mathrm{V}_{\max }[\mathrm{S}]}+\frac{1}{\mathrm{~V}_{\max }}$

where $\alpha=1+\frac{[\mathrm{I}]}{\mathrm{K}_{\mathrm{i}}}$.

\section{Molecular docking}

Molecular docking analysis of sixteen synthesized compounds ( 2 and 4-18) were performed to determine the relative affinity with elastase protein using the AutoDock Vina release 1.1.2. ${ }^{52}$ The crystal structure of elastase (PDB ID: 1GVK) with $0.95 \AA$ A was extracted from Protein Data Bank. ${ }^{53,54}$ The active site of enzymes was identified through the selection of amino acids within $8 \AA$ radius from catalytic amino acids His57, Asp102, Ser119.55,56 The 3D structures of all compounds were drawn, optimized, and protonated using MarvinSketch software (ChemAxon). ${ }^{57}$ The protein structure was set using the AutoDock Tools. ${ }^{53}$ Binding energy was estimated using AutoDock 4 implemented in PyRx platform release 0.8. Docked structures were visualized and edited using PyMOL version $1.3 .{ }^{58}$ The docking calculations were performed with default parameters: population size, 150; maximum number of energy evaluations, 25000000; maximum number of generations, 27000; rate of gene mutation, 0.02 ; rate of crossover, 0.08 ; window size, 10 ; maximum interactions, 300 . 


\section{Supplementary Information}

Supplementary information is available free of charge at http://jbcs.sbq.org.br as PDF file.

\section{Acknowledgments}

This work was supported by FAPEMIG, CAPES, FINEP and CNPq.

\section{References}

1. Castro, G. T.; Blanco, S. E.; Giordano, O. S.; Molecules 2000, 5,422 .

2. Al-ghorbani, M.; Thirusangu, P.; Gurupadaswamy, H. D.; Girish, V.; Neralagundi, H. G. S.; Prabhakar, B. T.; Khanum, S. A.; Bioorg. Chem. 2016, 65, 73.

3. Shi, J. B.; Chen, L. Z.; Wang, Y.; Xiou, C.; Tang, W. J.; Zhou, H. P.; Liu, X. H.; Yao, Q. Z.; Eur. J. Med. Chem. 2016, 124. 729.

4. Ma, X.; Zhang, X.; Dai, H.; Yang, S.; Yang, L.; Gu, S.; Zheng, Y.; He, Q.; Chen, F.; Bioorg. Med. Chem. 2011, 19, 4601.

5. Al-ghorbani, M.; Ranganatha, V. L.; Prashanth, T.; Begum, A. B.; Khanum, S. A.; Pharma Chem. 2013, 5, 269.

6. Belluti, F.; Bartolini, M.; Bottegoni, G.; Bisi, A.; Cavalli, A.; Andrisano, V.; Rampa, A.; Eur. J. Med. Chem. 2011, 46, 1682.

7. Venu, T. D.; Shashikanth, S.; Khanum, S. A.; Naveen, S.; Firdouse, A.; Sridhar, M. A.; Prasad, J. S.; Bioorg. Med. Chem. 2007, 15, 3505 .

8. Jing, Y.; Ai, Q.; Lin, L.; Dai, J.; Jia, M.; Zhou, D.; Che, Q.; Wan, J.; Jiang, R.; Zhang, L.; Int. Immunopharmacol. 2014, 19, 373.

9. Zrinka, R.; Dimitra, H. L.; Eleni, P.; Jan, B.; Branka, Z.; Med. Chem. Res. 2011, 20, 210.

10. Miyano, M.; Deason, J. R.; Nakao, A.; Stealey, M. A.; Villamil, C. I.; Sohn, D. D.; Mueller, R. A.; J. Med. Chem. 1988, 31, 1052.

11. Martins, F. T.; Assis, D. M.; dos Santos, M. H.; Camps, I.; Veloso, M. P.; Juliano, M. A.; Alves, L. C.; Doriguetto, A. C.; Eur. J. Med. Chem. 2009, 44, 1230.

12. Kashmiri, L.; Pinki, Y.; Ashwani, K.; Anil, K.; Avijit, K. P.; Bioorg. Chem. 2018, 77, 236.

13. Yu, B.; Qi, P.; Shi, X.; Huang, R.; Guo, H.; Zheng, Y.; Yu, D.; Liu, H.; Eur. J. Med. Chem. 2016, 117, 241.

14. Mareddy, J.; Suresh, N.; Kumar, C. G.; Kapavarapu, R.; Jayasree, A.; Pal, S.; Bioorg. Med. Chem. Lett. 2017, 27, 518.

15. Kant, R.; Singh, V.; Nath, G.; Awasthi, S. K.; Agarwal, A.; Eur. J. Med. Chem. 2016, 124, 218.

16. Hou, W.; Luo, Z.; Zhang, G.; Cao, D.; Li, D.; Ruan, H.; Ruan, B. H.; Su, L.; Xu, H.; Eur. J. Med. Chem. 2017, 138, 1042.

17. Dheer, D.; Singh, V.; Shankar, R.; Bioorg. Chem. 2017, 71, 30.
18. Shaikh, M. H.; Subhedar, D. D.; Nawale, L.; Sarkar, D.; Khan, F. A. K.; Sangshetti, J. N.; Shingate, B. B.; Med. Chem. Commun. 2015, 6, 1104.

19. Reddy, V. G.; Reddy, T. S.; Nayak, V. L.; Prasad, B.; Reddy, A. P.; Ravikumar, A.; Taj, S.; Kamal, A.; Eur. J. Med. Chem. 2016, 122, 164.

20. Pokhodylo, N.; Shyyka, O.; Matiychuk, V.; Sci. Pharm. 2013, 81,663 .

21. Tan, W.; Li, Q.; Wang, H.; Liu, Y.; Zhang, J.; Dong, F.; Guo, Z.; Carbohydr. Polym. 2016, 142, 1.

22. Xu, Z.; Zhang, S.; Song, X.; Qiang, M.; Zaosheng, L.; Bioorg. Med. Chem. Lett. 2017, 27, 3643.

23. Tan, W.; Li, Q.; Li, W.; Dong, F.; Guo, Z.; Int. J. Biol. Macromol. 2016, 82, 404.

24. Saraiva, M. T.; Krüger, R.; Baldinotti, R. S. M.; Lenardão, E. J.; Luchese, C.; Savegnago, L.; Wilhelm, E. A.; Alves, D.; J. Braz. Chem. Soc. 2016, 27, 41.

25. Gontijo, V. S.; Espuri, P. F.; Alves, R. B.; Camargos, L. F.; Santos, F. V.; Judice, W. A. S.; Marques, M. J.; Freitas, R. P.; Eur. J. Med. Chem. 2015, 101, 24.

26. Gonzalez-Calderon, D.; Mejia-Dionicio, M. G.; Morales-Reza, M. A.; Aguirre-de-Paz, J. G.; Ramirez-Villalva, A.; MoralesRodríguez, M.; Fuentes-Benites, A.; Gonzalez-Romero, C.; Bioorg. Chem. 2016, 69, 1.

27. Di Pietro, O.; Alencar, N.; Esteban, G.; Viayna, E.; Szalaj, N.; Vázquez, J.; Juarez-Jimenez, J.; Sola, I.; Perez, B.; Sole, M.; Unzeta, M.; Munoz-Torrero, D.; Luque, F. J.; Bioorg. Med. Chem. 2016, 24, 4835.

28. Manohar, S.; Khan, S. I.; Rawat, D. S.; Chem. Biol. Drug Des. 2011, 78, 124.

29. Raj, R.; Gut, J.; Rosenthal, P. J.; Kumar, V.; Bioorg. Med. Chem. Lett. 2014, 24, 756.

30. Gumrukcuoglu, N.; Sokmen, B. B.; Ugras, S.; Ugras, H. I.; Yanardag, R.; J. Enzyme Inhib. Med. Chem. 2013, 28, 89.

31. Sokmen, B. B.; Gumrukcuoglu, N.; Ugras, S.; Ugras, H. I.; Yanardag, R.; J. Enzyme Inhib. Med. Chem. 2013, 28, 72.

32. Ruivo, E. F. P.; Gonçalves, L. M.; Carvalho, L. A. R.; Guedes, R. C.; Hofbauer, S.; Brito, J. A.; Archer, M.; Moreira, R.; Lucas, S. D.; ChemMedChem 2016, 11, 2037.

33. Assis, D. M.; Gontijo, V. S.; Pereira, I. O.; Santos, J. A. N.; Camps, I.; Nagem, T. J.; Ellena, J.; Izidoro, M. A.; Tersariol, I. L. S.; de Barros, N. M. T.; Doriguetto, A. C.; dos Santos, M. H.; Juliano, M. A.; J. Enzym. Inhib. Med. Chem. 2013, 28, 661.

34. de Almeida, L.; Alves, K. F.; Maciel-Rezende, C. M.; Jesus, L. O. P.; Pires, F. R.; Junior, C. V.; Izidoro, M. A.; Júdice, W. A. S.; dos Santos, M. H.; Marques, M.; J. Biomed. Pharmacother. 2015, 75, 93.

35. Pereira, I. O.; Assis, D. M.; Juliano, M. A.; Cunha, R. L. O. R.; Barbieri, C. L.; do Sacramento, L. V. S.; Marques, M. J.; dos Santos. M. H.; J. Med. Food 2011, 14, 557. 
36. Doriguetto, A. C.; Martins, F. T.; Ellena, J.; Salloum, R.; Nagem, T. J.; Chem. Biodiversity 2007, 4, 488.

37. Martins, F. T.; Cruz Júnior, J. W.; Derogis, P. B. M. C.; dos Santos, M. H.; Veloso, M. P.; Ellena, J.; Doriguetto, A. C.; J. Braz. Chem. Soc. 2007, 18, 1515.

38. Freitas, P. G.; Castilho, T. E.; de Almeida, L.; Maciel-Rezende, C. M.; Costa, L. T.; Viegas Junior, C.; Marques, M. J.; dos Santos, M. H.; da Silveira, N. J. F.; J. Braz. Chem. Soc. 2018, 29,515 .

39. Folquitto, L. R. S.; Nogueira, P. F.; Espuri, P. F.; Gontijo, V. S.; de Souza, T. B.; Marques, M. J.; Carvalho, D. T.; Júdice, W. A. S.; Dias, D. F.; Med. Chem. Res. 2017, 26, 1149.

40. Hlasta, D. J.; Ackerman, J. H.; J. Org. Chem. 1994, 59, 6184.

41. Galibert, M.; Wartenberg, M.; Lecaille, F.; Saidi, A.; Mavel, S.; Joulin-Giet, A.; Korkmaz, B.; Bromme, D.; Aucagne, V.; Delmas, A. F.; Lalmanach, G.; Eur. J. Med. Chem. 2018, 144, 201.

42. Shi-Ping, Z.; Wen-Ya, W.; Kun, F.; Zheng-Gang, L.; Guo-Qiang, D.; Zhen-Yuan, M.; Jian-Zhong, Y.; Wan-Nian, Z.; Chun-Quan, S.; Chin. Chem. Lett. 2014, 25, 229.

43. Alvarez, S. G.; Alvarez, M. T.; Synthesis 1997, 4, 413.

44. Segel, I. H.; Enzyme Kinetics Behavior and Analysis of Rapid Equilibrium and Steady-State Enzyme Systems; John Wiley \& Sons: New York, 1993, p. 470-473.

45. Chen, Z.; Lu, D.; Weber, S. G.; J. Pharm. Sci. 2009, 98, 229.

46. Müller, I.; Acta Crystallogr., Sect. D: Struct. Biol. 2017, 73, 79.

47. Huang, S.-Y.; Zou, X.; Int. J. Mol. Sci. 2010, 11, 3016.

48. Sawyer, L.; Shotton, D. M.; Campbell, J. W.; Wendell, P. L.; Muirhead, H.; Watson, H. C.; J. Mol Biol. 1978, 118, 137.
49. Farady, C. J.; Craik, C. S.; ChemBioChem 2010, 11, 2341.

50. Sayer, J. M.; Louis, J. M.; Proteins 2009, 75, 556.

51. Leatherbarrow, R. J.; GraFit, version 5.0; Erithacus Software Ltd., Staines, UK, 1992.

52. Trott, O.; Olson, A. J.; J. Comput. Chem. 2010, 31, 455.

53. Katona, G.; Wilmouth, R. C.; Wright, P. A.; Berglund, G. I.; Hajdu, J.; Neutze, R.; Schofield, C. J.; J. Biol. Chem. 2002, 277, 21962.

54. Rose, P. W.; Prlić, A.; Altunkaya, A.; Bi, C.; Bradley, A. R.; Christie, C. H.; Di Costanzo, L.; Duarte, J. M.; Dutta, S.; Feng, Z.; Green, R. K.; Goodsell, D. S.; Hudson, B.; Kalro, T.; Lowe, R.; Peisach, E.; Randle, C.; Rose, A. S.; Shao, C.; Tao, Y.-P.; Valasatava, Y.; Voigt, M.; Westbrook, J. D.; Woo, J.; Yang, H.; Young, J. Y.; Zardecki, C.; Berman, H. M.; Burley, S. K.; Nucleic Acids Res. 2017, 45, D271.

55. Hajjar, E.; Broemstrup, T.; Kantari, C.; Witko-Sarsat, V.; Reuter, N.; FEBS J. 2010, 277, 2238.

56. Katona, G.; Wilmouth, R. C.; Wright, P. A.; Berglund, G. I.; Hajdu, J.; Neutze, R.; Schofield, C. J.; J. Biol. Chem. 2002, 277, 21962.

57. MarvinSketch software, version 16.6.20; Chemaxon, Budapest, Hungry, 2016.

58. http://www.pymol.org, accessed on March 21, 2018.

Submitted: May 25, 2018

Published online: August 20, 2018 